\title{
Relationship between Lipoprotein Lipase Activity and Plasma Sex Steroid Levels in Obese Women
}

Per-Henrik Iverius and John D. Brunzell

Department of Medicine, Division of Metabolism Endocrinology and Nutrition, University of Washington, Seattle, Washington 98195; Veterans Administration Medical Center and Department of Internal Medicine, Division of Endocrinology and Metabolism, University of Utah, Salt Lake City, Utah 84132

\begin{abstract}
In obese women $(n=16)$ at their usual weight, fasting adipose tissue lipoprotein lipase (LPL) activity, obtained by elution with serum and heparin at $4^{\circ}$ and $37^{\circ} \mathrm{C}$, was inversely correlated to plasma estradiol levels $(r=-0.724 ; P=0.002)$ and $(r$ $=-0.641 ; P=0.010)$, respectively. Furthermore, fasting postheparin plasma LPL activity during a heparin infusion, showed an even stronger inverse correlation to plasma estradiol when measured at $60 \mathrm{~min}(r=-0.815 ; P<0.001)$. None of the above parameters was correlated to the body mass index.

Postprandial LPL activity in postheparin plasma, measured $10 \mathrm{~min}$ after a heparin injection, showed a strong positive correlation with plasma free testosterone $(r=0.780 ; P$ $=0.001$ ). Neither of these parameters was correlated with the body mass index. The origin of this LPL activity is presently unknown but could conceivably represent a pool of LPL from skeletal muscle.
\end{abstract}

Since it has been shown convincingly that estrogen decreases adipose tissue LPL activity in the rat, the present studies strongly suggest that estradiol is a major negative regulator of fasting adipose tissue LPL activity in women.

\section{Introduction}

Although men and women are clearly different regarding circulating plasma lipoprotein concentrations (1) and body fat distribution (2) the underlying mechanisms are incompletely understood. In both these aspects of lipid metabolism, lipoprotein lipase (LPL) ${ }^{1}$ probably has a critical role. The enzyme hydrolyzes the triglyceride transported in very low density lipoproteins (VLDL) and chylomicrons thereby making their triglyceride fatty acids available for uptake in various tissues including adipose tissue (3). Thus the enzyme participates in the metabolism of major lipoprotein species as well as in the regulation of fat cell size.

The concentration of most of the hormones reported to either stimulate (4-9) or inhibit $(5,10-12)$ rat adipose tissue LPL activity, are the same in both sexes. Sex steroids on the other hand account for many differences between the sexes,

Address reprint requests to Dr. Iverius, Endocrinology Section (111E), Veterans Administration Medical Center, 500 Foothill Boulevard, Salt Lake City, UT 84148.

Received for publication 2 October 1987 and in revised form 21 March 1988.

1. Abbreviations used in this paper: LPL, lipoprotein lipase (EC 3.1.1.3).

The Journal of Clinical Investigation, Inc.

Volume 82, September 1988, 1106-1112 making it likely that these hormones also account for sex differences in LPL regulation. Convincing evidence for their effect on LPL has so far mainly been obtained in the rat. Thus, estradiol reduces adipose tissue LPL activity in both intact and gonadectomized animals (13-20), while progestin, only affecting female adipose tissue (16), counteracts the estrogen effects on LPL (16-17). Androgen inhibition of adipose tissue LPL appears to result from estradiol formed by aromatization rather than from a direct effect (21).

In man, some studies have failed to demonstrate effects of oral estrogen on either adipose tissue (22) or postheparin plasma LPL (22-25), while others have reported that oral estrogen inhibits postheparin plasma LPL in postmenopausal women $(26,27)$. Oral or percutaneous progestin alone $(24,28$, 29 ), or in combination with estrogen (30), may enhance LPL activity in adipose tissue $(28,29)$ and postheparin plasma $(24)$, respectively, while no effect on postheparin plasma LPL has been observed with low dose oral contraceptive (31) and anabolic steroid $(31,32)$.

Only a few human studies have explored the relationship between endogenous sex steroid levels in plasma and LPL activity. Thus no relationship has been demonstrated between either estradiol and postheparin plasma LPL (33) or estrone and adipose tissue LPL activity (28). Correlations between testosterone levels and LPL have been reported to be negative for adipose tissue $(33)$, and either positive $(28,34)$ or absent $(33)$, for postheparin plasma.

In summary, available data regarding sex steroid effects on adipose tissue and postheparin plasma LPL activity in man are contradictory and have failed to reproduce the strong and consistent effects observed in the rat. However, endogenous sex steroid levels in plasma were measured only in a few of the human studies.

The present study was undertaken in an attempt to resolve some of the discrepancies and to explore the role of endogenous sex steroids in the regulation of adipose tissue and postheparin plasma LPL in women. Precise and specific assays for LPL were employed. In addition, postheparin plasma lipase activities were determined after a standard bolus heparin injection and during prolonged heparin infusion, to take into account the possibility that there are differences in the kinetics of LPL release from different tissues. The results strongly suggest that circulating estradiol is an important negative regulator of adipose tissue LPL in fasting women. Furthermore, postheparin plasma in the postprandial state contains an LPL fraction of unknown origin, that is strongly correlated to plasma testosterone.

\section{Methods}

Human subjects. Obese females $(n=16)$ within $10 \%$ of their usual weight were admitted to the University of Washington Clinical Re- 
Table I. Anthropometric Measures and Laboratory Screening

\begin{tabular}{|c|c|c|c|c|c|c|c|c|c|}
\hline Subject & Age & Height & Weight & $\begin{array}{l}\text { Body mass } \\
\text { index }\end{array}$ & Glucose & Thyroxine & TSH & Triglycerides & Cholesterol \\
\hline & $y r$ & $\mathrm{~cm}$ & $k g$ & $\mathrm{~kg} / \mathrm{m}^{2}$ & $m g / d l$ & $\mu g / d l$ & $\mu U / m l$ & $m g / d l$ & $m g / d l$ \\
\hline 1 & 25 & 165 & 106.2 & 39.2 & 102 & 6.5 & 3.6 & 112 & 180 \\
\hline 2 & 56 & 157 & 78.1 & 31.7 & 101 & 5.7 & 6.0 & 96 & 218 \\
\hline $3^{*}$ & 22 & 164 & 73.8 & 27.4 & 81 & 5.8 & 5.2 & 73 & 320 \\
\hline 4 & 43 & 162 & 103.0 & 39.2 & 94 & 5.8 & 3.2 & 71 & 169 \\
\hline 5 & 41 & 158 & 91.6 & 36.7 & 107 & 7.0 & 4.2 & 87 & 231 \\
\hline 6 & 39 & 173 & 98.2 & 32.8 & 109 & 6.5 & 4.6 & 83 & 226 \\
\hline 7 & 46 & 163 & 80.5 & 30.3 & 71 & 5.4 & 2.6 & 146 & 184 \\
\hline 8 & 34 & 169 & 87.3 & 30.6 & 85 & 6.8 & 3.5 & 127 & 193 \\
\hline 9 & 27 & 173 & 76.5 & 25.5 & 90 & 5.6 & 4.0 & 110 & 197 \\
\hline $10^{\ddagger}$ & 57 & 163 & 84.4 & 32.0 & 89 & 7.7 & 12.5 & 106 & 176 \\
\hline 11 & 24 & 180 & 115.6 & 35.7 & 82 & 5.8 & 3.7 & 118 & 183 \\
\hline $12^{\S}$ & 37 & 163 & 130.2 & 49.0 & 81 & 12.5 & - & 127 & 204 \\
\hline 13 & 61 & 168 & 96.6 & 34.2 & 89 & 8.0 & 9.0 & 119 & 246 \\
\hline 14 & 22 & 164 & 100.9 & 37.5 & 74 & 6.8 & - & 61 & 149 \\
\hline $15^{\S}$ & 66 & 155 & 72.6 & 30.2 & 92 & 9.0 & 4.3 & 41 & 197 \\
\hline $16^{*}$ & 33 & 172 & 117.9 & 40.1 & 85 & 7.1 & 4.0 & 195 & 229 \\
\hline
\end{tabular}

* Hyperlipidemia: subject 3 has hypercholesterolemia and subject 16 both hypertriglyceridemia and hypercholesterolemia (44). ${ }^{\ddagger}$ Borderline hypothyroidism. ${ }^{\S}$ Treated hypothyroidism: subjects 12 and 15 were maintained on 0.2 and $0.15 \mathrm{mg} / \mathrm{d}$, respectively, of L-thyroxine.

search Center after informed consent had been obtained as approved by the Human Subjects Review Committee at the University of Washington. The subjects were fed a formula diet consisting of $15 \%$ (kcal/ total $\mathrm{kcal}$ ) protein, $40 \%$ fat and $45 \%$ carbohydrate, which was split in five isocaloric feedings between 8 a.m. and 8 p.m. The formula diet was supplemented with multivitamins, vitamin $\mathrm{C}$ and ferrous sulfate. Caloric intake for weight maintenance was calculated from an empirical formula (unpublished observation). ${ }^{2}$ Subjects were weighed daily in nightgown with empty bladder before breakfast. Over a 2-wk study period the weight change in the 16 subjects ranged from -68 to +49 $\mathrm{g} / \mathrm{d}$ (mean $\pm \mathrm{SD},-6.5 \pm 38.3$ ). The subjects, except two on thyroid (Table I) and one on low-dose estrogen replacement (Table IV), were taken off their usual medications during the study. Other data from these subjects have been reported previously (35).

Clinical chemistry. Fasting morning blood samples were obtained after the initial weight adjustment period had been completed. An automated chemical profile and assays for thyroxine, $\mathrm{T}_{3}$-resin uptake, and thyrotropin were done in the clinical laboratory at the University of Washington Hospital. Radioimmunoassays for total serum estrone (36) and testosterone (37) as well as determinations of free testosterone by equilibrium dialysis (38) were performed by Nichols Institute, San Juan Capistrano, CA. Total serum estradiol was measured by a kit (unpublished observations) from Pantex Laboratories, Santa Monica, CA. In menstruating subjects, these samples were obtained on the fourteenth day from the start of the last menstrual period. Plasma lipid determinations were performed at the Northwest Lipid Research Clinic following a standard protocol (39).

Lipoprotein lipase. Fasting LPL activity in gluteal adipose tissue needle biopsies from below the postero-lateral iliac crest, and postheparin plasma was determined as described previously $(35,40)$. Before assay, the enzyme was recovered from the adipose tissue by elution with serum and heparin at $4^{\circ}$ and $37^{\circ} \mathrm{C}$, and by extraction with detergent. The fractions obtained by elution supposedly represent mainly extracellular enzyme and are therefore a better index of the physiologi-

2. Equation describing the relationship between caloric intake (I; kcal/ $\mathrm{kg}$ per d) required for weight maintenance on a metabolic ward and body mass index $\left(\mathrm{BMI} ; \mathrm{kg} / \mathrm{m}^{2}\right): \mathrm{I}=52.2-0.752 \times \mathrm{BMI}$. cally active enzyme than detergent-extracted enzyme, which measures the total LPL activity in the tissue (35). Adipose tissue LPL activity was related to either wet tissue weight or cell number after determination of average fat cell size (41).

Postheparin plasma LPL activity was calculated as the fraction of total lipolytic activity that was inhibited by an antiserum to LPL whereas the noninhibited fraction was taken as hepatic triglyceride lipase activity (42). Fasting activity was measured $10 \mathrm{~min}$ after the injection of heparin $(60 \mathrm{U} / \mathrm{kg})$ as well as at several time points during a high-dose 6-h heparin infusion $(35,43)$. Postprandial postheparin plasma activity was measured by injecting heparin $(60 \mathrm{U} / \mathrm{kg}) 120 \mathrm{~min}$ after receiving the first feeding of the day and plasma was sampled 10 min after the injection.

Data analysis. An AT\&T Personal Computer 6300 equipped with the SPSS/PC+ statistical software (SPSS Inc., Chicago, IL) and SigmaPlot (version 3.0) scientific graph software (Jandel Scientific, Sausalito, CA) was used for statistical computations and production of graphs.

\section{Results}

Characterization of study population. Anthropometric measures and results of laboratory screening are shown in Table $\mathrm{I}$. None of the subjects had diabetes, two had hyperlipidemia, two had treated hypothyroidism and one had borderline hypothyroidism (Table I). In addition, four subjects were postmenopausal and two had oligomenorrhea (Table IV). The results of LPL determinations in adipose tissue and postheparin plasma as well as plasma sex steroid levels are displayed in Tables II-IV, respectively.

Relationship between LPL activity and plasma estrogen levels. The correlation matrix displayed in Table $\mathrm{V}$ demonstrates that plasma estradiol but not estrone levels showed significant negative correlations with adipose tissue as well as fasting postheparin plasma LPL activity. Only adipose tissue LPL activity eluted at either $4^{\circ} \mathrm{C}$ or $37^{\circ} \mathrm{C}$ and expressed per unit weight, showed a significant correlation (Figs. $1 A$ and 2). The LPL activity in postheparin plasma sampled at 10,30 , and 
Table II. Adipose Tissue LPL Activity and Fat Cell Size

\begin{tabular}{|c|c|c|c|c|c|c|c|}
\hline \multirow[b]{2}{*}{ Subject } & \multicolumn{3}{|c|}{ Activity per weight } & \multicolumn{3}{|c|}{ Activity per cell } & \multirow[b]{2}{*}{ Cell size } \\
\hline & $\begin{array}{l}\text { Elution } \\
\text { at } 4^{\circ} \mathrm{C}\end{array}$ & $\begin{array}{l}\text { Elution } \\
\text { at } 37^{\circ} \mathrm{C}\end{array}$ & $\begin{array}{l}\text { Detergent } \\
\text { extraction }\end{array}$ & $\begin{array}{l}\text { Elution } \\
\text { at } 4^{\circ} \mathrm{C}\end{array}$ & $\begin{array}{l}\text { Elution } \\
\text { at } 37^{\circ} \mathrm{C}\end{array}$ & $\begin{array}{l}\text { Detergent } \\
\text { extraction }\end{array}$ & \\
\hline & \multicolumn{3}{|c|}{$\mathrm{nmol} \cdot \min ^{-1} \cdot \mathrm{g}^{-1}$} & \multicolumn{3}{|c|}{$\mathrm{nmol} \cdot \mathrm{min}^{-1} \cdot 10^{-6} \mathrm{cells}$} & $\mu g /$ cell \\
\hline 1 & 42.2 & 48.2 & 169 & 30.0 & 34.3 & 120 & 0.710 \\
\hline 2 & 39.1 & 87.2 & 228 & 25.2 & 56.1 & 146 & 0.644 \\
\hline 3 & 43.2 & 124.0 & 273 & 27.0 & 77.1 & 171 & 0.624 \\
\hline 4 & 33.4 & 76.9 & 190 & 21.3 & 49.1 & 121 & 0.639 \\
\hline 5 & 27.4 & 43.8 & 211 & 17.0 & 27.2 & 130 & 0.619 \\
\hline 6 & 29.0 & 78.1 & 177 & 20.6 & 55.5 & 126 & 0.711 \\
\hline 7 & 61.4 & 112.0 & 316 & 40.5 & 74.0 & 209 & 0.660 \\
\hline 8 & 11.0 & 31.8 & 157 & 7.1 & 20.5 & 101 & 0.645 \\
\hline 9 & 22.1 & 65.3 & 223 & 12.0 & 35.6 & 121 & 0.544 \\
\hline 10 & 50.2 & 107.0 & 305 & 32.7 & 70.0 & 199 & 0.651 \\
\hline 11 & 27.1 & 52.1 & 145 & 16.7 & 32.1 & 89 & 0.616 \\
\hline 12 & 37.1 & 92.0 & 226 & 18.4 & 45.5 & 112 & 0.496 \\
\hline 13 & 59.4 & 106.0 & 267 & 34.5 & 61.8 & 155 & 0.581 \\
\hline 14 & 33.5 & 77.2 & 216 & 18.8 & 43.3 & 121 & 0.561 \\
\hline 15 & 68.4 & 154.0 & 298 & 46.8 & 106.0 & 204 & 0.685 \\
\hline 16 & 22.5 & 66.6 & 223 & 20.9 & 61.7 & 207 & 0.927 \\
\hline
\end{tabular}

All values were obtained after a 12 -h overnight fast.

$60 \mathrm{~min}$ after the start of a heparin infusion showed significant negative correlations at all three time points (Table V). The strongest and most significant was the correlation between fasting $60 \mathrm{~min}$ postheparin plasma LPL activity and plasma estradiol (Fig. $3 A$ ). Since the relationships in Figs. $1 A$ and $3 A$

Table III. Postheparin Plasma LPL Activity

\begin{tabular}{|c|c|c|c|c|c|}
\hline \multirow[b]{2}{*}{ Subject } & \multicolumn{3}{|c|}{ Fasting } & \multirow{2}{*}{$\frac{\text { Fed }}{10 \mathrm{~min}^{*}}$} & \multirow{2}{*}{$\begin{array}{l}\begin{array}{l}\text { Difference } \\
\text { fasting-fed }\end{array} \\
10 \mathrm{~min}\end{array}$} \\
\hline & $10 \mathrm{~min}^{*}$ & $30 \mathrm{~min}$ & $60 \mathrm{~min}$ & & \\
\hline & \multicolumn{5}{|c|}{$\mathrm{nmol} \cdot \mathrm{min}^{-1} \cdot \mathrm{ml}^{-1}$} \\
\hline 1 & 180 & 239 & 212 & 169 & 11 \\
\hline 2 & 287 & 456 & 509 & - & - \\
\hline 3 & 213 & 262 & 256 & 147 & 66 \\
\hline 4 & 179 & 137 & 148 & 154 & 25 \\
\hline 5 & 177 & 171 & 99 & 104 & 73 \\
\hline 6 & 218 & 285 & 266 & 156 & 62 \\
\hline 7 & 244 & 332 & 332 & 177 & 67 \\
\hline 8 & 102 & 147 & 146 & 124 & -22 \\
\hline 9 & 213 & 262 & 256 & 147 & 66 \\
\hline 10 & 218 & 296 & 315 & - & - \\
\hline 11 & 259 & 170 & 175 & 194 & 65 \\
\hline 12 & 239 & 259 & 324 & 163 & 76 \\
\hline 13 & 267 & 433 & 516 & 133 & 134 \\
\hline 14 & 280 & 357 & 354 & 244 & 36 \\
\hline 15 & 360 & 630 & 609 & 184 & 176 \\
\hline 16 & 234 & 304 & 244 & 132 & 102 \\
\hline
\end{tabular}

* The means \pm SD of paired cases $(n=14)$ were $226.1 \pm 59.9$ and $159.1 \pm 34.5$, respectively, and significantly different by the paired $t$ test $(t=5.09 ; P=0.000$, two-tailed probability). appear to be nonlinear, the data were also plotted with a logarithmic scale on the abscissa (Fig. $1 B$ and $3 B$ ). This maneuver improved the correlations from $r=-0.724(P=0.002 ; n=15)$ and $r=-0.815(P=0.0002 ; n=15)$ to $r=-0.781(P$ $=0.0006)$ and $r=-0.860(P=0.0000)$, respectively.

Table IV. Plasma Levels of Sex Steroids

\begin{tabular}{|c|c|c|c|c|}
\hline Subject & Estradiol & Estrone & Testosterone & $\begin{array}{c}\text { Free } \\
\text { testosterone }\end{array}$ \\
\hline & \multicolumn{2}{|c|}{$p g / m l$} & $n g / d l$ & $p g / m l$ \\
\hline 1 & - & - & 27 & 5.2 \\
\hline $2^{*}$ & 58 & 2.7 & 10 & 0.9 \\
\hline 3 & 141 & 88.0 & 21 & 3.4 \\
\hline 4 & 227 & 91.0 & 11 & 2.3 \\
\hline 5 & 207 & 35.0 & 15 & 2.6 \\
\hline $6^{\ddagger}$ & 141 & 55.0 & 36 & 4.4 \\
\hline $7^{8}$ & 65 & 56.0 & 20 & 2.9 \\
\hline 8 & 197 & 76.0 & 18 & 3.0 \\
\hline 9 & 90 & 20.0 & 21 & 4.3 \\
\hline $10^{* \|}$ & 55 & 75.0 & 24 & 3.1 \\
\hline 11 & 136 & 107.0 & 28 & 4.3 \\
\hline $12^{\ddagger}$ & 110 & 80.0 & 22 & 3.7 \\
\hline $13^{*}$ & 25 & 16.0 & 10 & 1.4 \\
\hline 14 & 90 & 115.0 & 43 & 7.6 \\
\hline $15^{*}$ & 45 & - & 32 & 3.6 \\
\hline 16 & 235 & 148.0 & 10 & 1.8 \\
\hline
\end{tabular}


Table V. Correlations between LPL Activity and Plasma Sex Steroid Levels

\begin{tabular}{lllll}
\hline Enzyme source & Estradiol & Estrone & Testosterone & $\begin{array}{c}\text { Free } \\
\text { testosterone }\end{array}$ \\
\hline $\begin{array}{l}\text { Adipose tissue } \\
\quad \text { Per gram }\end{array}$ & & & & \\
$\quad$ Elution at $4^{\circ} \mathrm{C}$ & $-0.7239^{*}$ & -0.2903 & 0.0766 & -0.1331 \\
$\quad$ Elution at $37^{\circ} \mathrm{C}$ & $-0.6414^{*}$ & -0.1265 & 0.1144 & -0.1434 \\
$\quad$ Detergent extraction & -0.6179 & -0.2141 & -0.0923 & -0.2558 \\
Per $10^{6}$ cells & & & & \\
$\quad$ Elution at $4^{\circ} \mathrm{C}$ & -0.6135 & -0.1814 & 0.0623 & -0.1725 \\
$\quad$ Elution at $37^{\circ} \mathrm{C}$ & -0.4818 & 0.0380 & 0.0729 & -0.2166 \\
$\quad$ Detergent extraction & -0.2935 & 0.0868 & -0.1685 & -0.3600 \\
Postheparin plasma & & & & \\
Fasting & & & & \\
$\quad 10$ min & $-0.6643^{*}$ & -0.0667 & 0.2780 & 0.0508 \\
$\quad 30$ min & $-0.7198^{*}$ & -0.3642 & 0.1590 & -0.1021 \\
$\quad 60$ min & $-0.8146^{\ddagger}$ & -0.4191 & 0.0890 & -0.1572 \\
Fed & & & & \\
$\quad 10$ min & -0.4520 & 0.4005 & $0.7775^{*}$ & $0.7804^{\ddagger}$ \\
Difference fasting-fed & & & & \\
10 min & -0.5298 & -0.2134 & -0.0581 & -0.3263 \\
\hline
\end{tabular}

Pearson correlation coefficients calculated after pairwise exclusion of missing variables.

${ }^{*} P \leq 0.01 ;{ }^{\ddagger} P \leq 0.001$ (two-tailed significance).

There were no significant correlations between degree of obesity, measured as the body mass index, and either of the above parameters of LPL activity or estradiol levels (data not shown).

Relationship between LPL activity and plasma androgen levels. A strong positive correlation was demonstrated between postprandial LPL activity in 10 min postheparin plasma and total as well as free plasma testosterone (Table V; Fig. 4). The postprandial LPL activity in 10 min postheparin plasma was significantly lower than the fasting activity (Table III) and the difference was strongly correlated to fasting adipose tissue LPL activity eluted at $37^{\circ} \mathrm{C}$ and expressed per unit weight $(r$ $=0.713 ; P=0.004 ; n=14$ ). Thus, feeding may have decreased the contribution from the adipose tissue to the postheparin plasma activity and thereby increased the proportion of en-

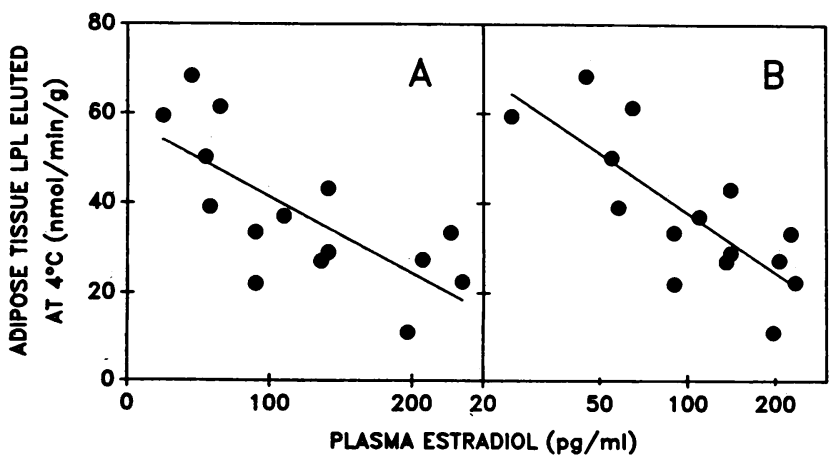

Figure 1. Linear $(A)$ and semilogarithmic $(B)$ regression of fasting adipose tissue LPL activity eluted at $4^{\circ} \mathrm{C}$, on plasma estradiol concentration. The linear $(r=-0.724 ; P=0.002)$ and semilogarithmic $(r=-0.781 ; P=0.0006)$ correlation coefficients were calculated after pairwise exclusion of a missing variable $(n=15)$.

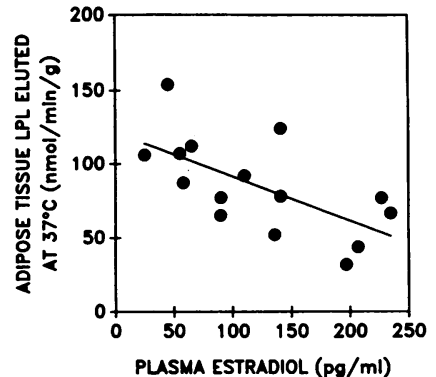

Figure 2. Linear regression of fasting adipose tissue LPL activity eluted at $37^{\circ} \mathrm{C}$, on plasma estradiol concentration. The correlation coefficient $(r=-0.641 ; P=0.010)$ was calculated after pairwise exclusion of a missing variable $(n=15)$.

zyme from other sites allowing a previously masked correlation to emerge.

There were no significant correlations between the body mass index and either the postprandial $10 \mathrm{~min}$ postheparin plasma enzyme or total and free testosterone levels (data not shown).

\section{Discussion}

The strong negative statistical correlations in women between plasma estradiol levels and LPL activity in both adipose tissue and postheparin plasma, have not been reported previously. These findings raise the question as to where the postheparin plasma enzyme originates. Since the bulk of the total body LPL probably resides in adipose tissue and skeletal muscle, each tissue contributing approximately equal amounts of enzyme (45), it is likely that both tissues are major contributors to postheparin plasma LPL activity. Previously, using the same subjects as in the present study, fasting postheparin plasma LPL activity at various times during a heparin infusion was shown to correlate positively with adipose tissue LPL activity eluted at $4^{\circ}$ and $37^{\circ} \mathrm{C}$, expressed per unit weight. Values obtained at $60 \mathrm{~min}$ after starting the infusion showed the best correlations (35). It would therefore seem plausible that the strong negative correlations between postheparin plasma LPL and estradiol (Table V) at least partly reflect inhibition of adipose tissue LPL by estrogen. Obviously, LPL from sources other than adipose tissue may also be inhibited by estrogens and contribute to the postheparin plasma lipase activity. For instance, some animal experiments have resulted in decreased

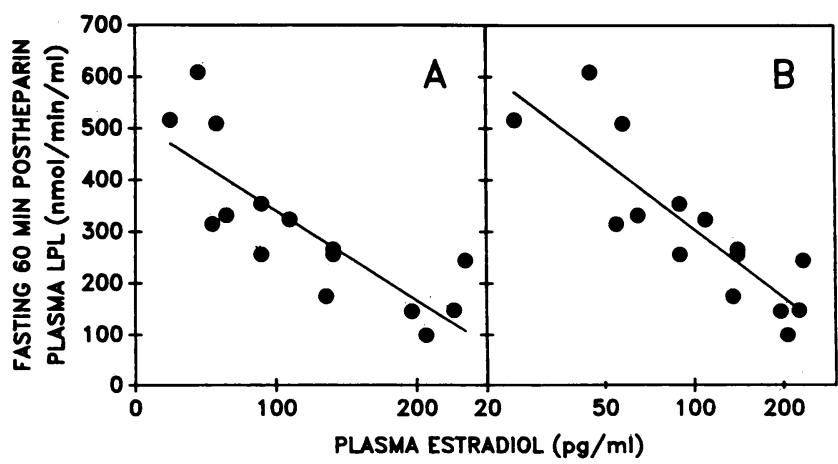

Figure 3. Linear $(A)$ and semilogarithmic $(B)$ regression of fasting postheparin plasma LPL activity, sampled at $60 \mathrm{~min}$ into a continuous heparin infusion, on plasma estradiol concentration. The linear $(r=-0.815 ; P=0.0002)$ and semilogarithmic $(r=-0.860 ; P$ $=0.0000$ ) correlation coefficients were calculated after pairwise exclusion of a missing variable $(n=15)$. 


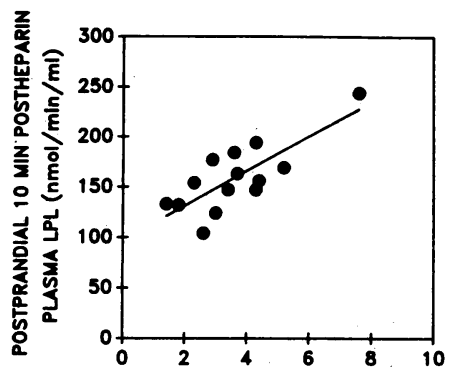

PLASMA FREE TESTOSTERONE (pg/ml)
Figure 4. Linear regression of postprandial plasma LPL activity, sampled 10 min after the injection of heparin, on plasma free testosterone concentration. The correlation coefficient $(r=0.780 ; P=0.001)$ was calculated after pairwise exclusion of two missing variables $(n=14)$.

skeletal muscle LPL activity by estrogen (18). Other experiments, however, have demonstrated the opposite effect (15). The noticeable correlation between postheparin plasma LPL and estrogen therefore remains to be fully explained.

Adipose tissue LPL activity from the gluteal site, also employed in the present study, is similar to that from the femoral site (46). In menstruating women, the femoral site has higher LPL activity than tissue from the abdominal site and only LPL from the former site is responsive to the hormonal changes of pregnancy and lactation (47). After the menopause, however, abdominal and femoral adipose tissue have similar LPL levels (30). The inverse correlation between gluteal adipose tissue LPL and estradiol suggests that this tissue site also is similar to femoral adipose tissue with regard to hormone responsiveness.

It should be noted that only the adipose tissue LPL recovered by elution, showed significant correlations with estradiol, while detergent-extracted enzyme did not. Since the former parameters presumably represent extracellular enzyme better than the latter (35), it might be argued that a putative direct effect of estradiol on the tissue could involve inhibition of enzyme secretion, stimulation of uptake and degradation, or removal of extracellular binding sites.

The population studied was heterogeneous in several respects. Although seven of the sixteen women did not have regular periods (Table IV), it was expected that these subjects would not pose a sampling problem since their estrogen levels could be expected to fluctuate less than in menstruating females. The one subject (No. 7) who had undergone hysterectomy would most likely be postmenopausal given her age (Table I) and estrogen level (Table IV). One postmenopausal subject (No. 10) was treated with $0.3 \mathrm{mg} / \mathrm{d}$ of conjugated equine estrogens (Premarin), a dose that is approximately one-third or less of full replacement. The main component of this preparation is estrone sulfate (48), which should act by conversion to estradiol. It is not known, however, to what extent the equine steroids contribute to unmeasurable estrogenic activity.

Heterogeneity of the study population was particularly apparent for age and degree of obesity (Table I). Nevertheless, the observed correlations should still be valid unless age and obesity were confounding variables. Since the subjects with the lowest estradiol levels were older than those with higher levels (Tables I and IV), it may be argued that age was a confounding variable. However, the correlations between age and adipose tissue LPL eluted at $4^{\circ} \mathrm{C}(r=0.643 ; P=0.007 ; n=16)$, at $37^{\circ} \mathrm{C}(r=0.567 ; P=0.022 ; n=16)$, and $60 \mathrm{~min}$ postheparin plasma LPL ( $r=0.670 ; P=0.005 ; n=16)$ were all weaker than the corresponding correlations with estradiol (Figs. $1 A, 2$, and $3 A$, respectively). Moreover, age was not significantly

correlated to estradiol $(r=-0.502 ; P=0.057 ; n=15)$. Finally, previous animal data have provided convincing evidence for inhibition of adipose tissue LPL by estradiol (see Introduction). The present data, interpreted in the latter context, therefore suggest that estradiol also inhibits adipose tissue LPL in man. It cannot be excluded, however, that age may have a minor effect on LPL, independent of estradiol.

Why then, have several previous human studies with two exceptions $(26,27)$ not found this striking correlation? There are at least two factors that alone or in combination conceivably could explain this discrepancy.

First, the likelihood of detecting an inhibition by exogenous estrogen would be the greatest in the postmenopausal female who has low endogenous estrogen levels and high lipase activity. Indeed, studies in which such effects have been reported were carried out in postmenopausal subjects (26-27). On the other hand, the administration of pure estrogen or birth control pills to menstruating women with moderate to high endogenous estrogen levels is likely not to alter total estrogenic activity in plasma due to suppression of ovarian production. Furthermore, the inhibitory effect of estradiol on adipose tissue $\mathrm{LPL}$ eluted at $4^{\circ} \mathrm{C}$ and $60 \mathrm{~min}$ postheparin plasma LPL, appears to reach a plateau at estradiol concentrations in the high normal range (Figs. $1 A$, and $3 A$ ) where all the cases have regular menstrual periods (Table IV). As expected, effects of exogenous estrogen on LPL have not been observed in menstruating women $(23,31)$.

Second, the sampling time is important in order to obtain a postheparin plasma fraction that shows a strong correlation with adipose tissue LPL activity. While most earlier studies have used postheparin plasma samples obtained at 10 to 15 min after a heparin injection, it was recently demonstrated that samples obtained $60 \mathrm{~min}$ after the start of a continuous heparin infusion shows the best correlation with the adipose tissue enzyme (35).

The absence of any relationship between degree of obesity and LPL activity expressed per unit weight of adipose tissue (see Results) has been reported previously in men (49). Although all the subjects were studied at their usual weight and in the eucaloric state, the difference between the highest and lowest LPL activity in adipose tissue measured by the different parameters varied from two- to severalfold (Table II). It may be surmised that these differences could reflect the different propensities for rate of weight gain should the caloric intake be increased above the level for weight maintenance.

The strong positive correlation between plasma testosterone and LPL activity in postprandial $10 \mathrm{~min}$ postheparin plasma (Fig. 4) was an unexpected finding. Since this enzyme fraction probably represents tissues other than the adipose tissue (see Results), skeletal muscle could conceivably be a major source. The fact that this tissue is a target organ for testosterone (50) as well as a documented source of LPL (51) lends further support for this notion. It has also been observed previously that postheparin plasma LPL activity released early ( 15 min) after a heparin injection is positively correlated to LPL activity in skeletal muscle (52). Contrary to the recent report by Lithell et al. (53), no correlation between any measure of adipose LPL activity and plasma testosterone levels were observed in the present study (Table V). It is possible, that the negative correlation noted by these authors in fact represents inhibition of adipose tissue LPL by estradiol formed by aroma- 
tization in that tissue of testosterone present in supranormal concentrations $(21,54)$.

Since steroid hormones do not display major short-term fluctuations in response to feeding, it is unlikely that testosterone alone was responsible for the decrease in LPL activity that took place in the 10-min postheparin plasma fraction over $2 \mathrm{~h}$. If testosterone is involved in the regulation of the postprandial 10-min postheparin plasma enzyme, the hormone would be more likely to have a long-term effect permissive for shortterm regulation. Conceivably, testosterone could control any of the events involved in the regulation of a secretory protein, e.g., synthesis, secretion, and degradation as well as the number of extracellular binding sites for the enzyme.

The notion that human LPL may be regulated by endogenous estrogens as well as androgens requires a comment about hepatic triglyceride lipase. In a number of studies, the latter enzyme measured in postheparin plasma has been shown to be inhibited by exogenous estrogens $(22-23,27,55)$ and stimulated by exogenous androgens and progestins $(32,56)$. The few studies addressing the effects of endogenous sex steroids on postheparin plasma hepatic triglyceride lipase found suppression of the enzyme during the luteal phase of the menstrual cycle (57) and during pregnancy (58). A negative correlation between estradiol levels and enzyme activity could be demonstrated only in the latter study (58).

In this study, there was no significant correlation between fasting $10 \mathrm{~min}$ postheparin plasma hepatic triglyceride lipase activity and either estradiol $(r=0.264 ; P=0.341 ; n=15)$ estrone $(r=0.264 ; P=0.362 ; n=14)$ or testosterone levels $(r$ $=-0.229 ; P=0.394 ; n=16$ ). Furthermore, there was no significant correlation between hepatic triglyceride lipase activity and any of the parameters of LPL activity in adipose tissue or postheparin plasma presented in this communication (data not shown), making it highly unlikely that any significant part of the hepatic triglyceride lipase was measured as LPL or vice versa. Thus, available data suggest that the hepatic triglyceride lipase is very sensitive to regulation by exogenous sex steroids, perhaps because the oral route of administration leads to transiently supranormal hormone concentrations in the hepatic circulation, whereas the role of endogenous sex steroids is still unclear. By contrast, the reverse situation seems to apply for LPL.

In summary, this study corroborates previous experiments in animals and strongly suggests that estradiol is a major negative regulator of fasting adipose tissue LPL in women, independent of degree of obesity. Together with the finding of a postheparin plasma LPL fraction that is positively correlated to plasma testosterone and probably unrelated to adipose tissue LPL, the present work also hints that both male and female sex steroids may participate in the regulation of LPL in more tissues and to a larger extent than previously thought.

\section{Acknowledgments}

The excellent technical assistance of Martha Kimura and Steven Hashimoto is gratefully acknowledged.

Support for this work was provided by the American Diabetes Association, the National Institutes of Health (DK-02456 and HL-30086), the General Clinical Research Center (RR 37) at the University of Washington, the Biomedical Research Support Grant (2 S07 RR0 5428) at the University of Utah, and the Veterans Administration.
Note added in proof. A recent report appearing in press since this paper was submitted has demonstrated that the rise in endogenous testosterone and estradiol levels following the injection of human chorionic gonadotropin (hCG) to prepubertal or early pubertal boys is accompanied by decreased fasting LPL activity in postheparin plasma (59).

\section{References}

1. Heiss, G., I. Tamir, C. E. Davis, H. A. Tyroler, B. M. Rifkind, G. Schonfeld, D. Jacobs, and I. D. Franz, Jr. 1980. Lipoprotein-cholesterol distributions in selected North American populations: The Lipid Research Clinics Program Prevalence Study. Circulation. 61:302-315.

2. Vague, J. 1953. La Differenciation Sexuelle Humaine: Ses incidences en pathologie. Masson, Paris.

3. Nilsson-Ehle, P., A. S. Garfinkel, and M. C. Schotz. 1980. Lipolytic enzymes and plasma lipoprotein metabolism. Annu. Rev. Biochem. 49:667-693.

4. Borensztajn, J., D. R. Samols, and A. H. Rubenstein. 1972. Effects of insulin on lipoprotein lipase activity in the rat heart and adipose tissue. Am. J. Physiol. 223:1271-1275.

5. Ashby, P., and D. S. Robinson. 1980. Effects of insulin, glucocorticoids and adrenaline on the activity of rat adipose-tissue lipoprotein lipase. Biochem. J. 188:185-192.

6. Vydelingum, N., R. L. Drake, J. Etienne, and A. H. Kissebah. 1983. Insulin regulation of fat cell ribosomes, protein synthesis, and lipoprotein lipase. Am. J. Physiol. 245:E121-E131.

7. Bourdeaux, A. M., R. Nordmann, and Y. Giudicelli. 1984. Stimulatory effects of adenosine, adenosine analogs and insulin on adipose tissue lipoprotein lipase activity and their prevention by phosphodiesterase inhibitors. FEBS (Fed. Eur. Biochem. Soc.) Lett. 178:132-136.

8. Bourdeaux, A. M., Y. Giudicelli, M. C. Rebourcet, J. Nordmann, and R. Nordmann. 1980. Influence of some gastrointestinal hormones on adipose tissue lipoprotein lipase activity in vitro: evidence of a stimulatory effect of pancreozymin and gastrin. Biochem. Biophys. Res. Commun. 95:212-219.

9. Speake, B. K., S. M. Parkin, and D. S. Robinson. 1986. Regulation of the synthesis of lipoprotein lipase in adipose tissue by dexamethasone. Biochim. Biophys. Acta. 881:155-157.

10. Patten, R. L. 1970. The reciprocal regulation of lipoprotein lipase activity and hormone-sensitive lipase activity in rat adipocytes. J. Biol. Chem. 245:5577-5584.

11. Bensadoun, A., and R. A. Marita. 1986. Dibutyryl cyclic AMP decreases the rate of lipoprotein synthesis in cultured adipocytes. Biochim. Biophys. Acta. 879:253-263.

12. Semb, H., J. Peterson, J. Tavernier, and T. Olivecrona. 1987. Multiple effects of tumor necrosis factor on lipoprotein lipase in vivo. J. Biol. Chem. 262:8390-8394.

13. Kim, H. J., and R. K. Kalkhoff. 1975. Sex steroid influence on triglyceride metabolism. J. Clin. Invest. 56:888-896.

14. Hamosh, M., and P. Hamosh. 1975. The effect of estrogen on the lipoprotein lipase activity in rat adipose tissue. J. Clin. Invest. 55:1132-1135.

15. Wilson, D. E., C. M. Flowers, S. I. Carlile, and K. S. Udall. 1976. Estrogen treatment and gonadal function in the regulation of lipoprotein lipase. Atherosclerosis. 24:491-499.

16. Gray, J. M., and G. N. Wade. 1980. Cytoplasmic estrogen but not progestin binding sites in male rat adipose tissue. Am. J. Physiol. 239:E237-E241.

17. Steingrimsdottir, L., J. Brasel, and M. R. C. Greenwood. 1980. Hormonal modulation of adipose tissue lipoprotein lipase may alter food intake in rats. Am. J. Physiol. 239:E162-E167.

18. Ramirez, I. 1981. Estradiol-induced changes in lipoprotein lipase, eating and body weight in rats. Am. J. Physiol. 240:E533-E538.

19. Gray, J. M., and M. R. C. Greenwood. 1983. Uterine and adipose tissue lipoprotein lipase activity in hormone-treated and pregnant rats. Am. J. Physiol. 245:E132-E137.

20. Dark, J., G. N. Wade, and I. Zucker. 1984. Ovarian modulation of lipoprotein lipase activity in white adipose tissue of ground squirrels. Physiol. Behav. 32:75-78. 
21. Gray, J. M., A. A. Nuñez, L. I. Siegel, and G. N. Wade. 1979. Effects of testosterone on body weight and adipose tissue: role of aromatization. Physiol. Behav. 23:465-469.

22. Applebaum, D. M., A. P. Goldberg, O. J. Pykälistö, J. D. Brunzell, and W. R. Hazzard. 1977. Effect of estrogen on post-heparin lipolytic activity. Selective decline in hepatic triglyceride lipase. J. Clin. Invest. 59:601-608.

23. Sauar, J., and K. T. Stokke. 1979. Plasma estrogens and hepatic lipase in postheparin plasma with special reference to liver disease. Clin. Chim. Acta 92:101-105.

24. Tikkanen, M. J., E. A. Nikkilä, T. Kuusi, and S. Sipinen. 1982. Effects of oestradiol and levonorgestrel on lipoprotein lipids and postheparin plasma lipase activities in normolipoproteinemic women. Acta Endocrinol. 99:630-635.

25. Tikkanen, M. J., T. Kuusi, E. A. Nikkilä, and T. Sane. 1984 Very low density lipoprotein triglyceride kinetics during hepatic lipase suppression by estrogen. Studies on the physiological role of hepatic endothelial lipase. FEBS (Fed. Eur. Biochem. Soc.) Lett. 181:160-164.

26. Glueck, C. J., P. Gartside, R. W. Fallat, and S. Mendoza. 1976. Effect of sex hormones on protamine inactivated and resistant postheparin plasma lipases. Metab. Clin. Exp. 25:625-632.

27. Tikkanen, M. J., T. Kuusi, E. Vartianen, and E. A. Nikkilä. 1979. Treatment of post-menopausal hypercholesterolemia with estradiol. Acta Obstet. Gynecol. Scand. Suppl. 88:83-88.

28. Lehtonen, A., M. Grönroos, J. Marniemi, P. Peltonen, M. Mäntylä, J. Niskanen, A. Rautio, and E. Hietanen. 1985. Effects of high dose progestin on serum lipids and lipid metabolizing enzymes in patients with endometrial cancer. Horm. Metab. Res. 17:32-34.

29. Rebuffe-Scrive, M., A. Basdevant, and B. Guy-Grand. 1983. Effect of local application of progesterone on human adipose tissue lipoprotein lipase. Horm. Metab. Res. 15:566.

30. Rebuffé-Scrive, M., P. Lönnroth, P. Mårin, C. Wesslau, P. Björntorp, and U. Smith. 1987. Regional adipose tissue metabolism in men and postmenopausal women. Int. J. Obes. 11:347-355.

31. Gevers Leuven, J. A., L. Havekes, H. A. van der Kooij-Pointer, R. J. H. Starmans, H. Jansen, M. L. Bouwhuis-Hoogerwerf, H. A. T. de Pagter, and L. W. Hessel. 1984. Effect of low-dose oral contraceptives on lipoproteins and lipolytic enzymes: differences between two commonly used preparations. Metab. Clin. Exp. 33:1039-1042.

32. Ehnholm, C., J. K. Huttunen, P. J. Kinnunen, T. A. Miettinen, and E. A. Nikkilä. 1975. Effect of oxandrolone treatment on the activity of lipoprotein lipase, hepatic lipase and phospholipase $A_{1}$ of human post-heparin plasma. N. Engl. J. Med. 292:1314-1317.

33. Mendoza, S. G., A. Zerpa, H. Carrasco, O. Colmenares, A. Rangel, P. S. Gartside, and M. L. Kashyap. 1983. Estradiol, testosterone, apolipoproteins, lipoprotein cholesterol, and lipolytic enzymes in men with premature myocardial infarction and angiographically assessed coronary occlusion. Artery. 12:1-23.

34. Breier, C., H. Drexel, H.-J.'Lisch, V. Mühlberger, M. Herold, and E. Knapp. 1985. Essential role of post-heparin lipoprotein lipase activity and of plasma testosterone in coronary artery disease. Lancet. i: $1242-1244$.

35. Iverius, P.-H., and J. D. Brunzell. 1985. Human adipose tissue lipoprotein lipase: changes with feeding and relation to postheparin plasma enzyme. Am. J. Physiol. 249:E107-E114.

36: Judd, H. J., W. E. Lucas, and S. S. C. Yen. 1976. Serum $17-\beta$-estradiol and estrone levels in postmenopausal women with and without endometrial cancer. J. Clin. Endocrinol. Metab. 43:272-278.

37. Kinouchi, T., L. Pages, and L. Horton. 1973. A specific radioimmunoassay for testosterone in peripheral plasma. J. Lab. Clin. Med. 82:309-316

38. Vermeulen, T., T. Stojca, and L. Verdonck. 1971. The apparent free testosterone concentration, an index of androgenicity. J. Clin. Endocrinol. 33:759-767.

39. Manual of Laboratory Operations, Lipid Research Clinics Program. 1974. Lipid and Lipoprotein Analysis. Vol. 1. U.S. Department of Health Education and Welfare. NIH Publication No. 75-628, Washington, DC.
40. Iverius, P.-H., and A. M. Östlund-Lindqvist. 1986. Preparation, characterization and measurement of lipoprotein lipase. Methods Enzymol. 129 Part B:691-704.

41. Sjöström, L., P. Björntorp, and J. Vrána. 1971. Microscopic fat cell size measurements of frozen-cut adipose tissue in comparison with automatic determinations of osmium-fixed fat cells. J. Lipid Res. 12:521-530.

42. Huttunen, J. K., C. Ehnholm, P. K. Kinnunen, and E. A. Nikkilä. 1975. An immunochemical method for the selective measurement of two triglyceride lipases in human postheparin plasma. Clin. Chim. Acta. 63:335-347.

43. Brunzell, J. D., A. Chait, E. A. Nikkilä, C. Ehnholm, J. K. Huttunen, G, Steiner. 1980. Heterogeneity of primary lipoprotein lipase deficiency. Metab. Clin. Exp. 29:624-629.

44. The Lipid Research Clinics Population Studies Data Book. 1980. The Prevalence Study. Vol. 1. U.S. Department of Health and Human Services. NIH Publication No. 80-1527, Washington, DC.

45. Lithell, H. 1977. Lipoprotein-Lipase Activity in Human Skeletal-Muscle and Adipose Tissue. Methodological and clinical studies. Abstracts of Uppsala Dissertations from the Faculty of Medicine. Vol. 272. Almqvist \& Wiksell, Stockholm, 35 pp.

46. Lithell, H., and J. Boberg. 1978. The lipoprotein-lipase activity of adipose tissue from different sites in obese women and the relationship to cell size. Int. J. Obes. 2:47-52.

47. Rebuffé-Scrive, M., L. Enk, N. Crona, P. Lönnroth, L. Abrahamson, U. Smith, and Per Björntorp. 1985. Fat cell metabolism in different regions of women. Effect of menstrual cycle, pregnancy, and lactation. J. Clin. Invest. 75:1973-1976.

48. Barnhart, E. R. 1988. Physicians Desk Reference. 42nd edition. Medical Economics Company, Oradell, NJ. 2355 pp.

49. Pykälistö, O. J., P. H. Smith, and J. D. Brunzell. 1975. Determinants of human adipose tissue lipoprotein lipase. Effect of diabetes and obesity on basal and diet-induced activity. J. Clin. Invest. 56:11081117.

50. Powers, M. L., and J. R. Florini. 1975. A direct effect of testosterone on muscle cells in tissue culture. Endocrinology. 97:1043-1047.

51. Lithell, H., J. Boberg, K. Hellsing, G. Lundqvist, and B. Vessby. 1978. Lipoprotein-lipase activity in human skeletal muscle and adipose tissue in the fasting and the fed states. Atherosclerosis. 30:89-94,

52. Reitman, J. S., F. C. Kosmakos, B. V. Howard, M. R. Taskinen, T. Kuusi, and E. A. Nikkilä. 1982. Characterization of lipase activities in obese Pima indians. Decrease with weight loss. J. Clin. Invest. 70:791-797.

53. Lithell, H., S. J. Nillius, T. Bergh, and I. Selinus. 1987. Metabolic profile in obese women with the polycystic ovary syndrome. Int. J. Obes. 11:1-8.

54. Longcope, D., T. Kate, and R. Horton. 1969. Conversion of blood androgens to estrogens in normal adult men and women. J. Clin. Invest. 48:2191-2201.

55. Tikkanen, M. J., E. A. Nikkilä, T. Kuusi, and S. Sipinen. 1982. High density lipoprotein-2 and hepatic lipase: reciprocal changes produced by estrogen and norgestrel. J. Clin. Endocrinol. Metab. 54:1113-1117.

56. Tikkanen, M. J., E. A. Nikkilä, T. Kuusi, and S. Sipinen. 1981. Reduction of plasma high-density lipoprotein ${ }_{2}$ cholesterol and increase of postheparin plasma hepatic lipase activity during progestin treatment. Clin. Chim. Acta. 115:63-71.

57. Tikkanen, M. J., T. Kuusi, E. A. Nikkilä, and U.-H. Stenman. 1986. Variation of postheparin plasma hepatic lipase by menstrual cycle. Metab. Clin. Exp. 35:99-104.

58. Kinnunen, P. K. J., H.-A. Unnérus, T. Ranta, C. Ehnholm, E. A. Nikkilä, and M. Seppälä. 1980. Activities of post-heparin plasma lipoprotein lipase and hepatic lipase during pregnancy and lactation. Eur. J. Clin. Invest. 10:469-474.

59. Sorva, R., T. Kuusi, L. Dunkel, and M.-R. Taskinen. 1988. Effects of endogenous sex steroids on serum lipoproteins and postheparin plasma lipolytic enzymes. J. Clin. Endocrinol. Metab. 66:408413. 